\title{
Photopletismography in dogs: identification of spectral elements and application in a surgical setting
}

\author{
Fotopletismografia em cães: identificação dos elementos espectrais e aplicação em ambiente \\ cirúrgico
}

\author{
Rui Assunção ${ }^{1,2}$, Clemente Rocha ${ }^{3}$, Luis Lobo ${ }^{1,2}$, Luís Monteiro Rodrigues ${ }^{3}$, João Requicha ${ }^{1,4 *}$ \\ ${ }^{1}$ Faculty of Veterinary Medicine, University Lusófona, Av. Campo Grande 376, 1749-024 Lisboa, Portugal; ${ }^{2}$ Hospital \\ Veterinário do Porto, Tv. de Silva Porto 174, 4250-475 Porto, Portugal; ${ }^{3} \mathrm{CBiOS}$ - Research Center for Biosciences and Health \\ Technologies, University Lusófona, School of Health Sciences \& Technologies, Av. Campo Grande 376, 1749-024 Lisboa, \\ Portugal; ${ }^{4} \mathrm{CECAV}$ - Veterinary and Animal Research Centre and AL4AnimalS, Department of Veterinary Sciences, University \\ of Trás-os-Montes e Alto Douro, Quinta de Prados, 5000-801 Vila Real, Portugal \\ *corresponding author / autor para correspondência: jfrequicha@utad.pt
}

\begin{abstract}
This pilot study aimed to assess cardiac and respiratory activity in dogs using photopletismography (PPG) during the presurgical period and to determine the spectral elements composing the measured PPG signal. The studied sample comprised four dogs, two males and two females, ranging from 7 months to 6 years old, from different breeds under anesthetic premedication. PPG signal was obtained at the tail using a PPG sensor connected to a Bitalino hardware board (Plux, Portugal) before and after premedication with $5 \mu \mathrm{g} / \mathrm{kg}$ dexmedetomidine and $0.35 \mathrm{mg} / \mathrm{kg}$ methadone by intramuscular injection. The data obtained was analyzed using Matlab (MathWorks, USA) and the PPG signal decomposed into its various frequencies by the Wavelet transform. The estimated minimum and maximum values of heart and respiratory activity were then identified. Seven waves were found. Correspondence with the cardiac and respiratory activities was determined after comparing its frequency with the normal heart and respiratory frequencies in dogs. This study demonstrated that the PPG technique is a valuable diagnostic tool to record both heart and respiratory frequencies in a clinical setting using a wireless system.
\end{abstract}

Keywords: dog, respiratory rate, heart rate, photoplethysmography, anesthesia, Wavelet transform

\section{Resumo}

Este estudo piloto teve como objetivos caracterizar através da fotopletismografia (FPG) a atividade cardíaca e respiratória no cão durante o período pré-cirúrgico e identificar os elementos espectrais que constituem esse sinal. A amostra em estudo incluiu quatro cães de diferentes raças, dois machos e duas fêmeas, entre os 7 meses e 6 anos de idade, submetidos a pré-medicação anestésica. O sinal de FPG foi obtido na cauda com um sensor de FPG ligado à placa hardware Bitalino (Plux, Portugal), antes e após pré-medicação com uma combinação de $5 \mu \mathrm{g} / \mathrm{kg}$ de dexmedetomidina e $0,35 \mathrm{mg} / \mathrm{kg}$ de metadona por via intramuscular. Os dados recolhidos foram analisados com recurso ao programa Matlab (MathWorks, EUA) e o sinal de FPG decomposto nas frequências que o constituem através da transformada de Wavelet. Posteriormente estimámos os valores máximos e mínimos das atividades cardíaca e respiratória. Encontrámos sete ondas estabelecidas em função da correspondência com as atividades cardíaca e respiratória normais do cão. Este ensaio permitiu demonstrar que a FPG é um instrumento de diagnóstico valioso para registar as frequências cardíaca e respiratória em ambiente clínico com recurso de um aparelho sem-fios.

Palavras-chave: cão, frequência respiratória, frequência cardíaca, fotopletismografia, anestesia, transformada de Wavelet 


\section{Introduction}

Wearable technology is already an integrative component of human and life sciences. In dogs, as in many other companion and working animals, wearable monitoring helps to obtain objective measurements in natural home settings, rather than relying on more subjective assessments of owners (1).

Photoplethysmography (PPG) is a non-invasive technique (2) with a wide range of clinical applications, being used in several devices, such as pulse oximeters and blood pressure detection systems (3). The PPG signal reflects changes in blood volume in the cutaneous and subcutaneous vascular plexus $(3,4)$, having a major component associated with heartbeat and respiration and others associated with low frequency influencers (5). Using signal analysis programs, it is possible to investigate the PPG signal and characterize its various constituents at the different frequencies of the PPG signal (3). In this way, the fluctuations associated with the cardiovascular, respiratory, and neuronal systems can be properly characterized and measured within the PPG signal (6). In 2013, Nilsson described the various frequencies found in PPG signals in humans, using the wavelet method to decompose a primary signal into its various elements (7).

In veterinary medicine, as of this writing, there is no data available on the frequency range of the various constituents of the PPG signal in the dog. However, it is possible to assume that the frequencies referring to cardiac and respiratory activities have higher frequency ranges, as in dogs (as reported by Houston in 2000), the heart rate might vary between 60 and 140 beats per minute (bpm), that is, between 1 and $2.3 \mathrm{~Hz}$. Likewise, the respiratory rate might vary between 18 and 36 breaths per minute (rpm), that is, between 0.3 and 0.6 $\mathrm{Hz}(8)$.

In the present study, the potential utility of the reflection PPG sensor was investigated in a veterinary surgical setting. Pulse wave data collected before and after the administration of sedative medication was obtained from the tails of dogs and analyzed.

\section{Introdução}

A tecnologia sem fios é já um dado adquirido nas ciências da vida com aplicação direta em humanos. Em cães, como em muitos outros animais de companhia e de trabalho, a monitorização adaptável ao corpo do animal ajuda a obter medições objectivas em ambientes domésticos naturais, em vez de depender de avaliações mais subjectivas dos proprietários (1).

A fotopletismografia (FPG) é um método não invasivo (2) com uma vasta aplicabilidade, incluindo a monitorização anestésica, sendo usada em diversos sensores, como por exemplo, em pulsioxímetros e esfingomanómetros (3). O sinal de FPG reflete mudanças no volume sanguíneo de vasos periféricos do plexo vascular cutâneo e subcutâneo $(3,4)$ especialmente determinado pelo batimento cardíaco e pela respiração, para além doutros componentes (5). Com recurso a programas de análise de sinal, é possível estudar o sinal de FPG e caracterizar os seus vários constituintes nas suas diferentes frequências (3). Desta forma, flutuações de onda associadas às actividades cardíaca, respiratória e neuronal podem ser descritas e quantificadas (6). Nilson (2013) descreveu, em humanos, as várias frequências que podem ser encontradas no sinal de FPG com recurso ao método de transformada de Wavelet que permite decompor um sinal primário nos seus vários constituintes (7).

Em medicina veterinária, não há até à data, dados relativos aos intervalos de frequência dos constituintes do sinal de FPG no cão, no entanto é possível assumir que as atividades cardíaca e respiratória do sinal de FPG têm intervalos de frequência elevados. De acordo com Houston (2000), a frequência cardíaca em cães pode variar entre 60 e 140 batimentos por minuto (bpm), isto é, entre 1,0 e $2,3 \mathrm{~Hz}$ enquanto que a frequência respiratória pode variar entre 18 e 36 respirações por minuto (rpm), isto é, entre 0,3 e $0,6 \mathrm{~Hz}(8)$.

No presente estudo investigámos o potencial interesse de utilização da FPG em ambiente cirúrgico. Os dados das ondas de pulso recolhidos na cauda de cães antes e depois da administração de medicamentos sedativos foram obtidos e analisados. 


\section{Materials and Methods}

This study was approved by the Ethics and Animal Welfare Committee of the Faculty of Veterinary Medicine of Lusófona University (Lisbon).

Four dogs age ranging from 7 months to 6 years old ( $4 \pm 2.8$ years), different breeds (Dalmatian, Golden Retriever, Portuguese Retriever, mixed breed), with body weights between $15-29 \mathrm{~kg}(20 \pm 7.8 \mathrm{~kg})$ and from different genders (two males and two females) were studied.

For each dog, we performed a trichotomy of a small area in the ventral part of the tail in order to improve the contact between the sensor and the skin (Figure 1); the choice of the tail as study site was due to ease of access and comfort for the animal. Data collection was carried out for 3 to 5 minutes followed by preanesthetic medication using $0.35 \mathrm{mg} / \mathrm{kg}$ methadone (Semfortan, Esteve, Spain) and $5 \mu \mathrm{g} / \mathrm{kg}$ dexmedetomidine (Dextomitor, Zoetis, USA) by intramuscular injection. After a waiting period of between 15 and 30 minutes to ensure the expected (sedative) effect of the medication, the PPG signal was collected again in the same anatomical region. The data was obtained with a PPG sensor connected to a Bitalino hardware (Plux, Portugal) (Figure 1), and later downloaded to the OpenSignals (r)evolution software (beta version v.2015) of Bitalino. Finally, data was analyzed using the MatLab software (MathWorks Inc, v. R2016a, USA) after selecting the column of obtained values and following the visualization of the corresponding pulse wave (Figures 2 and 3).

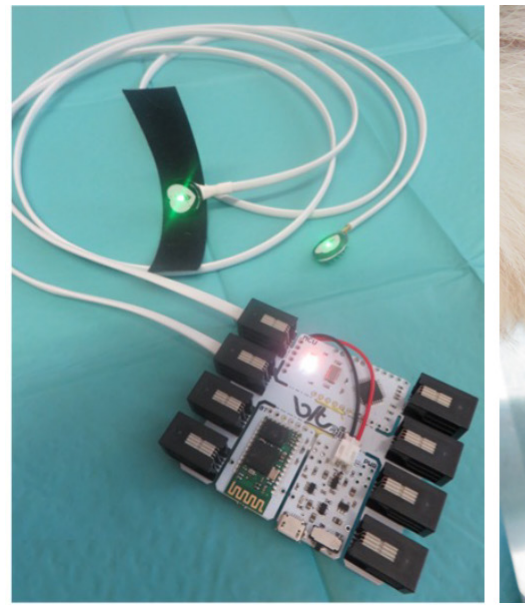

\section{Materiais e Métodos}

Este estudo foi realizado após aprovação pela Comissão de Ética e Bem-estar Animal da Faculdade de Medicina Veterinária da Universidade Lusófona (Lisboa).

A amostra estudada foi composta por quatro cães com idades compreendidas entre 7 meses e 6 anos de idade (4 \pm 2,8 anos), de diferentes raças (Dálmata, Golden Retriever, Perdigueiro Português e sem raça definida), com pesos vivos entre 15 e $29 \mathrm{~kg}(20 \pm 7,8 \mathrm{~kg})$, e de diferentes géneros (dois machos e duas fêmeas).

Em cada cão, procedeu-se à tricotomia de uma pequena área na região ventral da cauda, de forma a melhorar o contacto entre o sensor e a pele do animal (Figura 1); a escolha da cauda como local de estudo prende-se com a facilidade de acesso e conforto para o animal. No mesmo momento, foi realizada uma recolha de dados durante 3 a 5 minutos, sendo posteriormente efetuada a medicação pré-anestésica com o recurso a $0,35 \mathrm{mg} /$ $\mathrm{kg}$ metadona (Semfortan, Esteve, Espanha) e $5 \mu \mathrm{g} / \mathrm{kg}$ dexmedetomidina (Dexdomitor, Zoetis, EUA) através de injeção intramuscular. Após um período de cerca de 15 a 30 minutos de espera para efeito (sedativo) da medicação, os dados de FPG foram novamente recolhidos na mesma localização anatómica. Os dados foram obtidos com um sensor de FPG conectado a uma placa de hardware Bitalino (Plux, Portugal) (Figura 1). Depois, os sinais foram transferidos para o programa OpenSignals (r)evolution software (beta version $\mathrm{v}$. 2015) da Bitalino e avaliados com recurso ao software MathLab (MathWorks Inc, v. R2016a, EUA), após seleção da coluna de dados obtidos e após visualização da onda de pulso correspondente (Figuras 2 e 3 ).

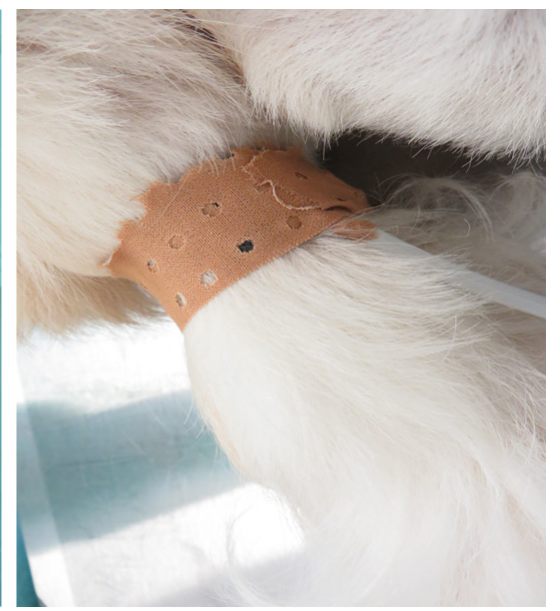

Figure 1 - Left, Bitalino equipment (Plux, Portugal), including the Bitalino hardware board and the respective sensors. Right, fixation of sensors on a dog's tail.

Figura 1 - Esqd $d^{a}$, Equipamento Bitalino (Plux, Portugal), incluindo a placa de hardware Bitalino e os respectivos sensores. $D r t^{a}$, fixação dos sensores na cauda de um cão. 
After selecting the data to be analyzed, the code 1 (see Appendix, taken from http://noc.ac.uk/using-science/ crosswavelet-wavelet-coherence) was applied, which identified the maximum amplitude peaks for each wave. The next step was to create an artificial sine signal to obtain an expression of conversion of periods into frequency. Thus, a sine equation with known frequencies was created in code 2 (line b). Later a trend line was created and translated by the following equation $\mathrm{y}=49.416 \mathrm{e}-0.057 \mathrm{x} ; \mathrm{R}^{2}=0.9999$.

After the creation of the artificial sine signal, the Wavelet transform for the PPG signal was calculated. Using code 3, the Wavelet transform decomposes the signal into a periodogram resuming all different frequency components (Figure 2). With the minimum and maximum period of each wave obtained in the periodogram, we were able to obtain, minimum and maximum frequencies for each wave using the described equation. Replacing the value of $x$ in the equation with the period value and then multiplying by 60 , we obtained the activity value per minute of each wave in the periodogram.

The protocols mentioned above were applied to each animal in all records obtained before and after administration of medication.
Após identificação dos dados a analisar, foi aplicado o código 1 (ver Apêndix, obtido de http://noc.ac.uk/ using-science/crosswavelet-wavelet-coherence) com o objetivo de identificar o pico de amplitude máxima de cada onda. O passo seguinte foi criar um sinal artificial seno, de forma a obter uma expressão de conversão de período em frequência. Assim sendo, uma equação seno com frequências conhecidas foi criada utilizando o código 2 (linha $b$ ). De seguida, uma linha de tendência foi criada e traduzida pela seguinte equação $y=49,416 e-0,057 x ; R^{2}=0,9999$.

Depois de gerarmos o sinal artificial seno, calculámos a transformada de Wavelet. Utilizando o código 3, a transformada de Wavelet decompôs o sinal primário num periodograma contendo as varias frequências dos diferentes componentes que o constituem (Figura 2).

Finalmente, foi calculado o período mínimo e máximo de cada onda do periodograma, através da equação previamente descrita. Os valores de frequência mínimos e máximos de cada onda foram obtidos, após substituir o valor de x na equação pelo valor de período de cada onda e, de seguida, multiplicando o resultado por 60 , foi obtido o valor de atividade por minuto de cada onda do periodograma.

O protocolo supracitado foi realizado para todos os registos obtidos antes e depois da pré-medicação e, individualmente, para cada animal.

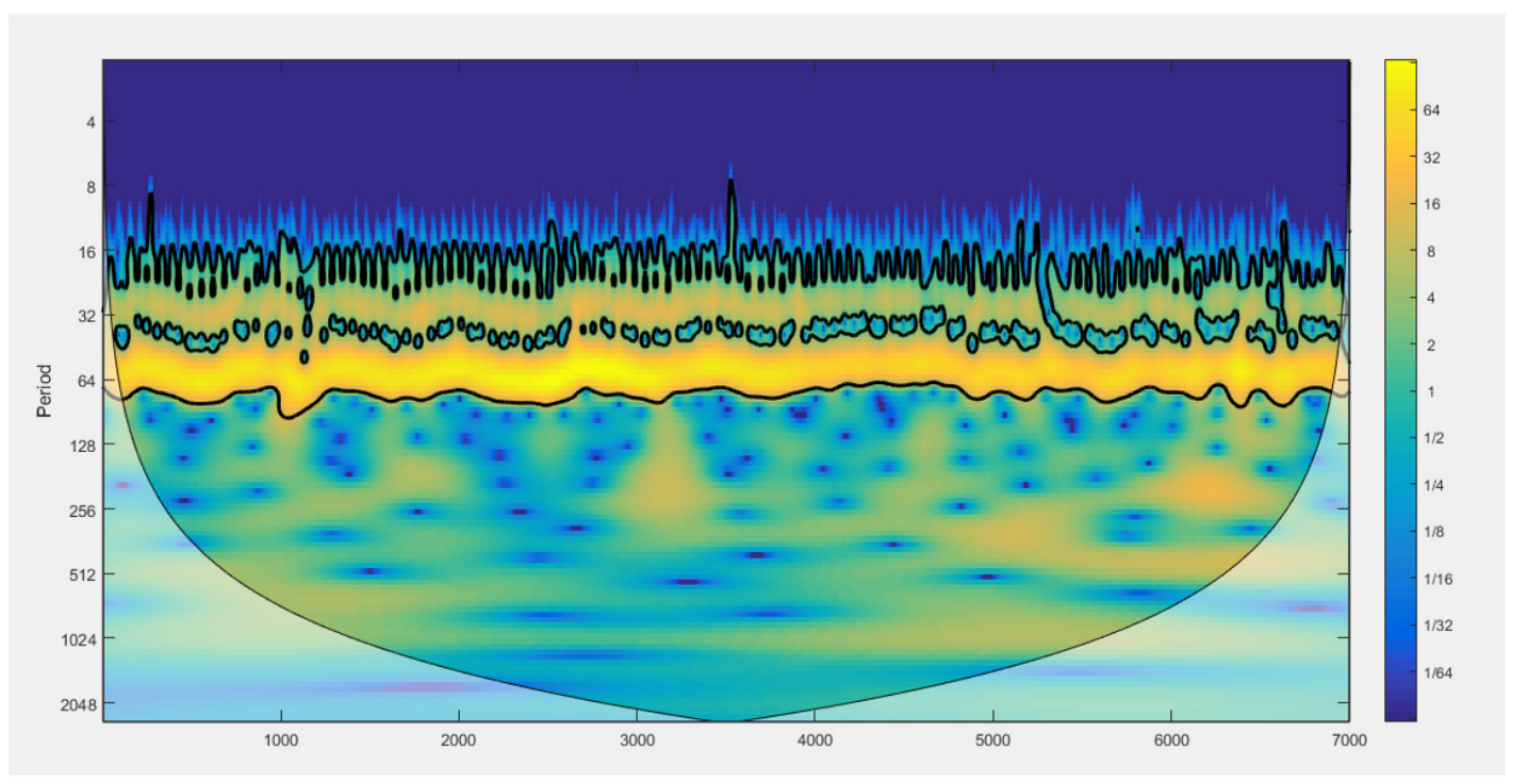

Figure 2 - Example of a Wavelet transform map (periodogram) obtained from the PPG signal in a dog.

Figura 2 - Exemplo dum mapa da transformada de Wavelet (periodograma) obtido do sinal de FPG num cão. 


\section{Results}

Figure 3 shows an original PPG signal and the respective decomposition by the Wavelet transform analysis.

The maximum and minimum frequencies of each wave of the different animals analyzed before medication were, respectively: wave $1-3.11$ and $9.43 \mathrm{~Hz}$; wave $2-1.18$ and $3.00 \mathrm{~Hz}$; wave $3-0.57$ and $0.97 \mathrm{~Hz}$; wave $4-0.23$ and $0.44 \mathrm{~Hz}$; wave $5-0.12$ and $0.21 \mathrm{~Hz}$; wave 6 (registered only in three animals) -0.09 and $0.14 \mathrm{~Hz}$ and wave 7 (registered only in two animals) - 0.04 and $0.09 \mathrm{~Hz}$. The PPG wave-frequencies obtained after administration of medication were: wave 1 -between 1 - 2.04 and $7.55 \mathrm{~Hz}$; wave $2-0.86$ and $2.04 \mathrm{~Hz}$; wave $3-0.28$ and $0.71 \mathrm{~Hz}$; wave $4-0.12$ and $0.26 \mathrm{~Hz}$; wave $5-0.07$ and $0.12 \mathrm{~Hz}$ and wave 6 (only one animal) between -0.08 and $0.10 \mathrm{~Hz}$.

\section{Resultados}

A Figure 3 mostra o sinal bruto da FPG e a respectiva decomposição pela análise da transformada de Wavelet.

As médias de valores de frequência máxima e mínima de cada onda constituinte do sinal de FPG antes da prémedicação foram, respetivamente, as seguintes: onda 1 - 3,11 e 9,43 Hz; onda 2 - 1,18 e 3,00 Hz; onda 3 - 0,57 e $0,97 \mathrm{~Hz}$; onda 4 - 0,23 e 0,44 Hz; onda 5 - 0,12 e 0,21 $\mathrm{Hz}$; onda 6 (registada em apenas três animais) - 0,09 e $0,14 \mathrm{~Hz}$ e onda 7 (registada em apenas dois animais) $-0,04$ e $0,09 \mathrm{~Hz}$. As frequências de onda obtidas no sinal de FPG após a pré-medicação foram: onda $1-2,04$ e 7,55 Hz; onda 2 - 0,86 e 2,04 Hz; onda 3 - 0,28 e 0,71 $\mathrm{Hz}$; onda 4 - 0,12 e 0,26 Hz; onda 5 - 0,07 e 0,12 Hz e onda $6-0,08$ e $0,10 \mathrm{~Hz}$ (apenas em um animal).
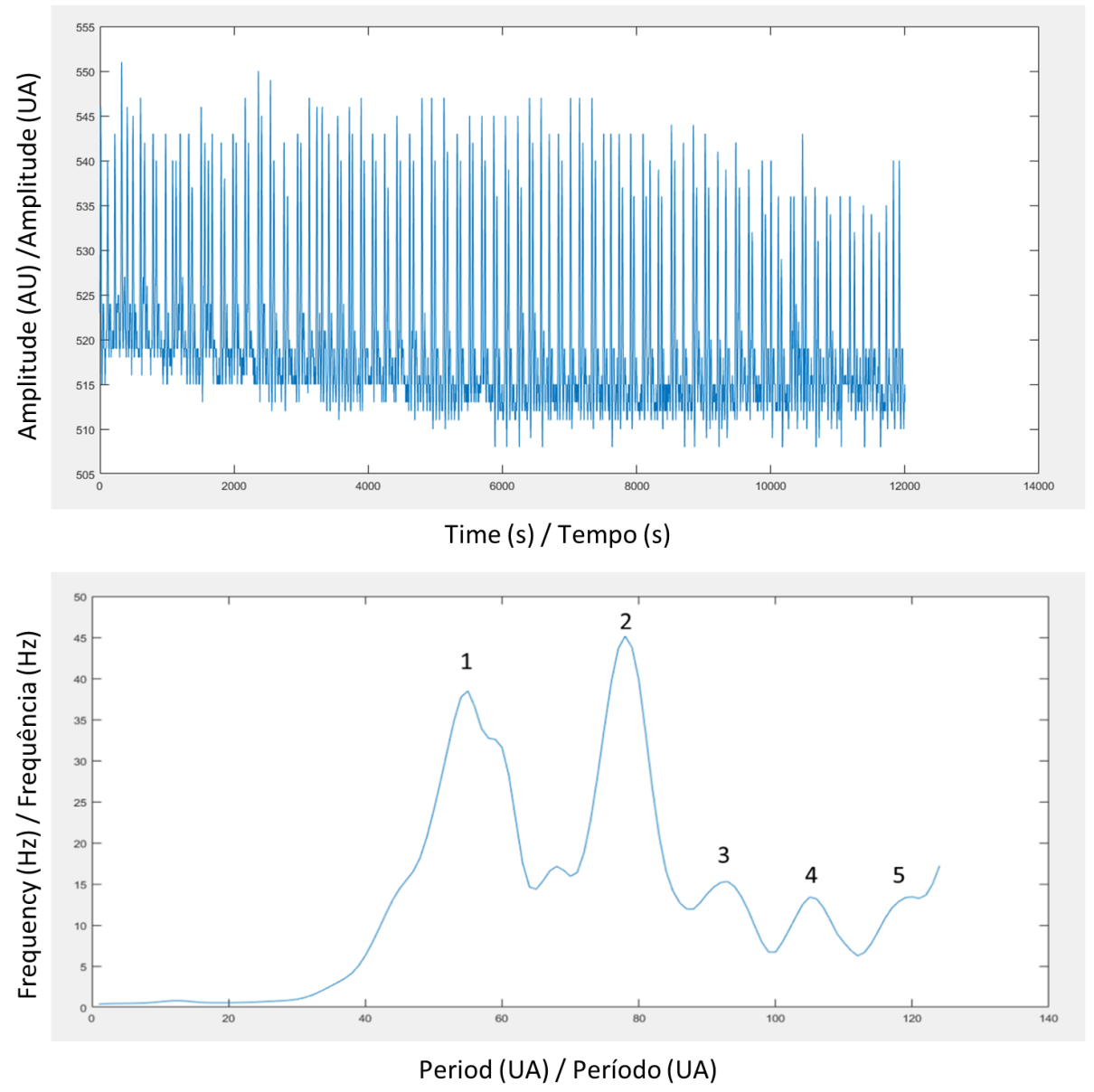

Figure 3 - Top, representation of the original photopletismography signal. Bottom, periodogram obtained from the Wavelet transform of the original signal. In this example five different waves, corresponding to different frequency intervals were identified (see text). The abscissa axis represents the period in arbitrary units. In this example, only five waves were identified.

Figura 3 - Em cima, registo original da onda de fotopletismografia. Em baixo, o periodograma obtido com a transformada de Wavelet depois de aplicada ao sinal original. Neste exemplo, foram identificados cinco diferentes intervalos de frequência (veja o texto). A abscissa representa o período em unidades arbitrarias. Neste exemplo, apenas cinco ondas foram identificadas. 


\section{Discussion}

This study illustrated, for the first time, the use of PPG as a monitoring technology for heart and respiratory rates in dogs in a surgical setting in veterinary medical practice, as well as the characterization of the different frequency waveforms present in the PPG signal.

Seven frequency waves were identified in these signals. Based on previous reports conducted in humans, rats and mice $(6,9)$, taking also into account the normal heart and respiratory rates in dogs, we assumed that the different frequency waveforms were related to (in descending order of frequency averages): (i) the harmonic of cardiac activity ( $1^{\text {st }}$ wave, between 3.11 and $9.43 \mathrm{~Hz}$ ), (ii) cardiac activity ( $2^{\text {nd }}$ wave, between 1.18 and $3.00 \mathrm{~Hz}$ ), (iii) respiratory activity $\left(3^{\text {rd }}\right.$ and $4^{\text {th }}$ waves, between 0.57 and $0.97 \mathrm{~Hz}$ and 0.23 and $0.44 \mathrm{~Hz}$, respectively), (iv) afferent vagal activity $\left(5^{\text {th }}\right.$ and $6^{\text {th }}$ waves, between 0.12 and $0.21 \mathrm{~Hz}$ and 0.09 and $0.14 \mathrm{~Hz}$, respectively) and (v) to sympathetic tone groundings $\left(7^{\text {th }}\right.$ wave, between 0.04 and $0.09 \mathrm{~Hz}$ ).

After the administration of the sedative medication, a decrease in the values for cardiac and respiratory activity and a decrease in the mean frequency of each wave were clear within the PPG signal. In medical practice, the utility of PPG in determining cardiac and respiratory rates are widely recognized $(7,10)$. In veterinary medicine, as far as our current knowledge goes, only one study has associated PPG with respiratory rate (11). Differences found regarding respiratory activity before and after administration of medication were not statistically significant, although a slight decrease in maximum respiratory activity and a (larger) decrease in minimum respiratory activity were detected. However, the purpose of this exploratory study was to test the applicability of this technology in the present setting, and in our opinion this goal was achieved.

We recognize the limitations involved in our study, including the small dimension of the sample used, the inter-individual variability, and the difficulty in selecting the ideal anatomical site for placing the sensor. Clearly, additional prospective animal studies are needed to validate the PPG technique in the present setting. Nevertheless, taking into account these results and our experience, for future studies we foresee (i) to include to a larger and more homogeneous population in terms of breed, age or live weight of the animals, in a way to reduce experimental bias, (ii) to use different anatomical sites, such as the ear or the extremities of the thoracic and pelvic limbs, (iii) to increase the duration of data collection to limit associated with animal movement

\section{Discussão}

Este estudo desenvolvido pela primeira vez em clinica veterinária, permitiu utilizar esta tecnologia como método de monitorização das frequências cardíaca e respiratória no cão em ambiente cirúrgico e, ao mesmo tempo, caracterizar as diferentes ondas presentes no sinal de FPG.

Neste sinal, foram identificadas sete intervalos de frequência. Baseado em estudos antes publicados incidindo em humanos ratos e ratinhos $(6,9)$ e tendo em conta o intervalo de frequências cardíacas e respiratórias considerado normal em cães, assumimos que as diferentes frequência de ondas estariam relacionadas com (por ordem descendente de média de frequências): (i) harmónico da atividade cardíaca, $1^{\mathrm{a}}$ onda entre $3,11 \mathrm{e}$ $9,43 \mathrm{~Hz}$ ), (ii) atividade cardíaca ( $2^{\mathrm{a}}$ onda entre 1,18 e 3,00 $\mathrm{Hz}$ ), (iii) atividade respiratória $\left(3^{\mathrm{a}}\right.$ e $4^{\mathrm{a}}$ ondas entre $0,57 \mathrm{e}$ $0,97 \mathrm{~Hz}$ e 0,23 e $0,44 \mathrm{~Hz}$, respetivamente), (iv) atividade vagal aferente $\left(5^{\mathrm{a}}\right.$ e $6^{\mathrm{a}}$ ondas entre 0,12 e $0,21 \mathrm{~Hz}$ e 0,09 e $0,14 \mathrm{~Hz}$ respetivamente) e (v) referente a alterações de tónus simpático ( $7^{\mathrm{a}}$ onda entre 0,04 e $0,09 \mathrm{~Hz}$ ).

Após a pré-medicação anestésica o FPG mostrou, como seria expectável, uma diminuição das atividade cardíaca e respiratória, e um decréscimo na frequência média de cada onda. Na prática médica, a utilidade pratica da FPGexistem vários estudos que provam a aplicabilidade e utilidade da FPG na quantificação das frequências cardíaca e respiratória está amplamente demonstrada $(7,10)$. Em Medicina Veterinária, de acordo com o nosso conhecimento actual, apenas um estudo exploraram a relação entre a FPG e a frequência respiratória em cães (11). Não obstante não terem sido obtidos resultados estatisticamente significativos, na análise da atividade respiratória antes e após a medicação préanestésica, foi possível detetar uma ligeira diminuição nos valores de atividade máxima respiratória e uma maior diminuição nos valores mínimos de atividade respiratória. Salientamos contudo, que o propósito do estudo era testar a aplicabilidade desta tecnologia no presente ambiente, o que, na nossa opinião, parece ter sido plenamente conseguido.

Reconhecemos as limitações do estudo, em especial no que respeita à reduzida amostra, à variabilidade interindividual dos cães estudados e a dificuldade na escolha da localização anatómica ideal para colocação do sensor. Contudo, tendo em conta os resultados obtidos e a nossa experiência, poderemos sugerir para estudos futuros (i) utilizar amostras mais homogéneas em termos de raça, idade e peso vivo, de forma a reduzir os vieses experimentais, (ii) usar diferentes locais como a orelha ou as 
and (iv) to conduct a comparative study of heart rate and respiratory rate obtained using other referenced techniques / methods in addition to PPG.

This study demonstrated the potential utility of such a wearable instrument in the clinical environment. The possibility of obtain biometrical data rapidly and easily, including cardiac and respiratory rates, from the photoplethysmography signal can help, in a simple way, to manage several conditions where the monitoring of these parameters gains a crucial importance to manage animals with chronic cardiopulmonary conditions, geriatric patients and convalescence animals upon surgery.

\section{Conclusion}

This pilot study demonstrated the relevance of reflection PPG, a non-invasive technique, to measure the heart and respiratory rates in dogs, and its utility in the clinical and ambulatory environment in veterinary medicine. It was also possible to confirm that the tail seems to be an appropriate anatomical area in dogs to collect these parameters.

\section{Authors Contributions Statement}

JR, LMR, conceptualization and study design; RA,LL experimental; RA, CR, HS, data curation; RA, JR, LMR, drafting, editing and reviewing; JR, LMR, supervision and final writing.

\section{Acknowledgements}

This work was funded by national funds through FCT - Foundation for Science and Technology, I.P., under the Scientific Employment Stimulus - Institutional Call - CEECINS/00127/2018 and supported by the project UIDB/CVT/00772/2020 and associated laboratory AL4AnimalS.

\section{Conflict of Interests}

Editors involved in this manuscripts' authorship had no participation in the review or decision process. All authors have stated that there are no financial and/or personal relationships that could represent a potential conflict of interest. extremidades dos membros torácicos ou pélvicos, (iii) recolher os dados durante um maior período de tempo, de forma a limitar a presença de artefactos associados ao movimento e (iv) proceder a um estudo comparativo de deteção das frequências cardíaca e respiratória com diferentes métodos para além da FPG.

Este trabalho permitiu demonstrar o potencial de interesse de um instrumento deste tipo em ambiente clínico. A possibilidade de obter dados biométricos como a frequência cardíaca e respiratória com a facilidade proporcionada pela fotopletismografia pode ajudar na gestão de múltiplas condições onde a monitorização destes parâmetros pode ser especialmente importante, como é o caso de animais com doenças cardiopulmonares crónicas, pacientes geriátricos ou mesmo em animais convalescentes após cirurgia.

\section{Conclusão}

Este estudo piloto demonstrou utilidade da FPG de reflexão, uma técnica não invasiva, na medição das frequências cardíaca e respiratória em cães, e a sua aplicabilidade em ambiente clínico e ambulatório em medicina veterinária. Foi também possível confirmar que a cauda parece ser um local anatómico adequado para a recolha destes parâmetros em cães.

\section{Declaração dos contributos de cada autor}

JR,LMR, concepção e desenho experimental; RA,LL experimentação; RA, CR, HS, curadoria de dados; RA, JR, LMR, elaboração do texto, edição e revisão; JR, LMR, supervisão e redacção final.

\section{Financiamento}

Este trabalho foi financiado por fundos nacionais através da FCT - Fundação para a Ciência e a Tecnologia, I.P., no âmbito do Estímulo ao Emprego Científico - Apoio Institucional - CEECINS/00127/2018 e suportado pelo projeto UIDB/CVT/00772/2020 e pelo laboratório associado AL4AnimalS.

\section{Conflito de interesse}

O Editor presente na autoria deste manuscrito não participou nos processos de pessoais revisão e/ou decisão. Os autores declararam não possuir quaisquer relações financeiras ou que possam configurar um potencial conflitos de interesse. 


\section{References / Referências}

1. Griffies, J. D., Zutty, J., Sarzen, M., \& Soorholtz, S. (2018). Wearable sensor shown to specifically quantify pruritic behaviors in dogs. BMC Veterinary Research, 14(1), 1-10. https://doi.org/10.1186/s12917-018-1428-x.

2. Dorlas, J. C., \& Nijboer, J. A. (1985). Photo-electric plethysmography as a monitoring device in anaesthesia. British Journal of Anaesthesia, 57, 524-530. https://doi.org/10.1093/bja/57.5.524.

3. Allen, J. (2007). Photoplethysmography and its application in clinical physiological measurement. Physiological Measurement, 28(3), R1-R39. https://doi.org/10.1088/0967-3334/28/3/R01.

4. Sahni, R. (2012). Noninvasive monitoring by photoplethysmography. Clinics in Perinatology, 39(3), 573-583. https://doi.org/10.1016/j. clp.2012.06.012.

5. Schultz-Ehrenburg, U., \& Blazek, V. (2001). Value of quantitative photoplethysmography for functional vascular diagnostics: current status and prospects. Skin Pharmacology and Applied Skin Physiology, 14(5), 316-323. https://doi.org/10.1159/000056362.

6. Nilsson, L. M. (2013). Respiration signals from photoplethysmography. Anesthesia and Analgesia, 117(4), 859-865. https://doi. org/10.1213/ANE.0b013e31828098b2.

7. Leonard, P., Beattie, T., Addison, P. S., \& Watson, J. N. (2003). Standard pulse oximeters can be used to monitor respiratory rate. Emergency Medicine Journal, 20, 524-525. https://doi.org/10.1136/emj.20.6.524.

8. Houston D. M. (2000). Clinical exam in dogs and cats. In O. M. Radostits, D. M. Houston, \& I. G. Mayhew (Eds.), Veterinary Clinical Examination \& Diagnosis (1st ed., pp. 98-101). W. B. Saunders Co. Ltd.

9. Silva, H., Roux, É., Gadeau, A. P., \& Rodrigues, L. M. (2020). Wavelet analysis of microcirculatory flowmotion reveals cardiovascular regulatory mechanisms-data from a beta-blocker. Applied Sciences, 10(11), 4000. https://doi.org/10.3390/app10114000

10. Karlen, W., Garde, A., Myers, D., Scheffer, C., Ansermino, J. M., \& Dumont, G. A. (2015). Estimation of respiratory rate from photoplethysmographic imaging videos compared to pulse oximetry. IEEE Journal of Biomedical and Health Informatics, 19(4), 13311338. https://doi.org/ 10.1109/JBHI.2015.2429746.

11. Nabutovsky, Y., Pavek, T., \& Turcott, R. (2012). Chronic performance of a subcutaneous hemodynamic sensor. Pacing Clinical Electrophysiology, 35(8), 919-26. https://doi.org/10.1111/j.1540-8159.2012.034 


\section{Appendix / Apêndix}

Code 1

(http://noc.ac.uk/using-science/crosswavelet-wavelet-coherence)

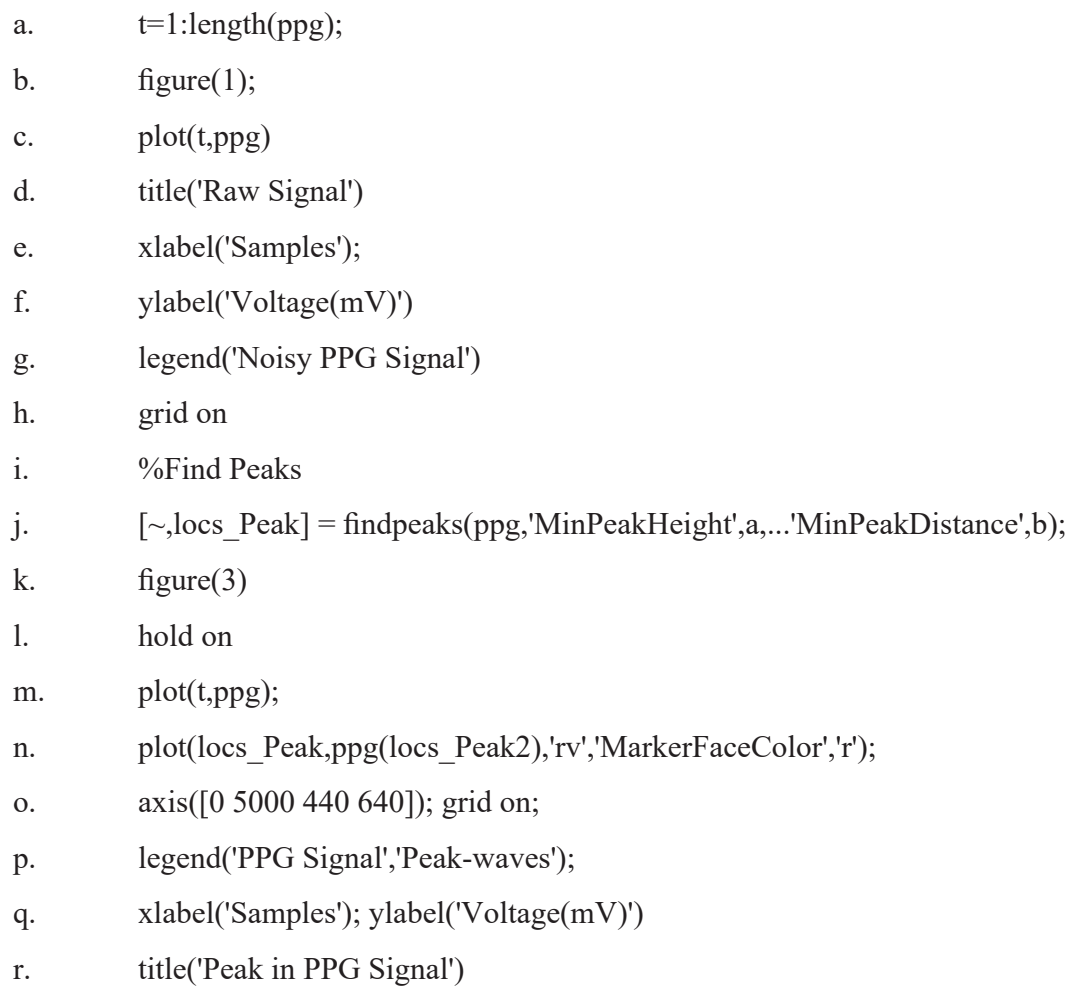

Note: At this point the letter 'a' has been replaced by the minimum amplitude of the waves of the signal 'ppg' and the letter ' $b$ ' by the minimum distance between the maximum amplitude peaks of each wave.

Code 2

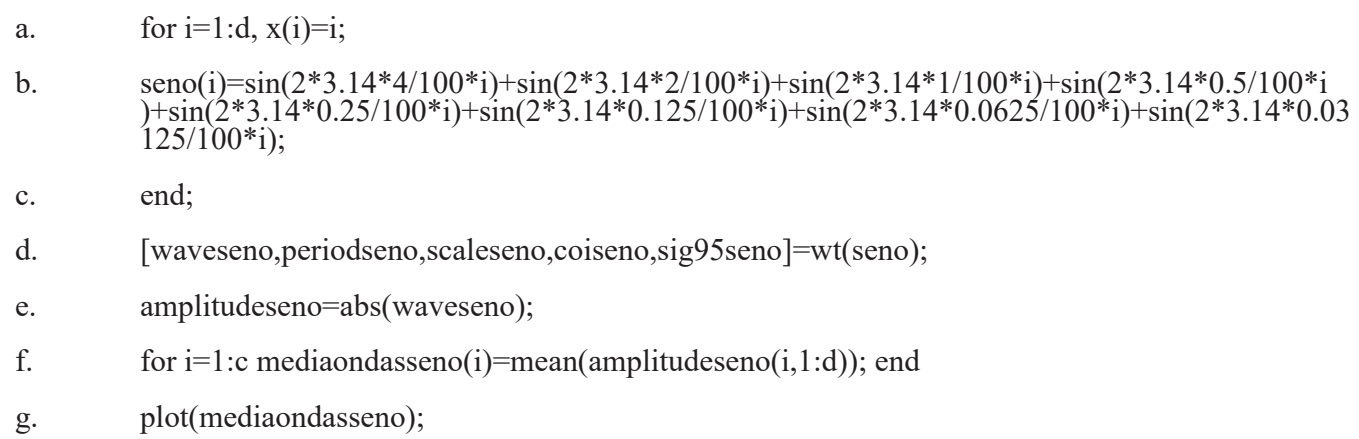

Note: At this point, the letter "d" represented the total number of points for analysis that were chosen in the original sign (on the abscissa axis of the original sign) and the letter "c" represented the number obtained by the equation.

\section{Code 3}
a. [waveppg,periodppg,scaleppg,coippg,sig95ppg]=wt(ppg);
b. [wave,period,scale,coi,sig95]=wt(ppg,'MakeFigure',1);
c. amplitudeppg=abs(waveppg);
d. for $i=1: c$ mediaondasppg(i)=mean(amplitudeppg(i,1:d)); end
e. figure(2), plot(mediaondasppg). 